\title{
Experimental Investigation on Design of Thickness for Flexible Pavement Subgrade Soils using CBR Approach
}

\author{
Y. Kamala Raju$^{1 *}$ and C. Vivek Kumar $^{2}$ \\ ${ }^{1,2}$ Assistant Professor, Dept. Of Civil Engg., GRIET, Hyd., IND
}

\begin{abstract}
This paper aim's to ensure that the transmitted stresses due to wheel load are adequately reduced, so that they will not exceed bearing capacity of the sub- grade. This present study deals with the design thickness of flexible pavements, where majority of the Indian roads are flexible pavements having bituminous layer. Earlier, due to the scarcity of cement and India went for flexible pavements with bituminous toppings. This flexible pavement is preferred over cement concrete roads as they have a great advantage that these can be strengthened and improved in stages with the growth of traffic. With a major advantage of this roads and their surfaces milled and recycled for rehabilitation. The flexible pavements are less expensive also about initial investment and maintenance. In this present study, the flexible pavement thickness is designed for both sub grade soils as per IRC:37-2001 code and its pavement thickness is calculated by California Bearing Ratio (CBR)method.
\end{abstract}

\section{Introduction}

Flexible bitumen which demonstrate the distortion of sub grade and the ensuing layers to the surface. Typically, black-top, is laid with no fortification or with a specific texture support that permits constrained stream or repositioning of the roadbed underground changes. The plan of adaptable asphalt is predicated on load dispersing normal for the part layers. The dark top asphalt including water and rock-bound macadam fall in this classification. Adaptable asphalt generally has low or unimportant adaptable quality adaptable in their basic activity. The vertical or compressive worries to the lower layers by grain move through contact purposes of granular structure transmits to the adaptable asphalt layers. The asphalt surface legitimately under the wheel load and is equivalent to contact pressure under the wheels will be most extreme to the vertical compressive pressure. The anxieties get diminished in the lower layer considering the capacity to convey the worry to huge zone looking like shortened cone. The asphalt is planned as an adaptable asphalt upon a dark cotton soil sub grade, the CBR strategy according to IRC 37-2001 is most fitting technique than accessible strategies. The asphalt is structured as an adaptable technique from which every strategy is planned dependent on their structure thickness from which every strategy has distinctive cost investigation of an area, from which CBR according to IRC is generally proper as far as cost examination. The asphalt is structured as an unbending asphalt; the technique recommended by IRC is generally appropriate.

\section{Review of Literature}

It is seen that flexible asphalts are progressively practical for lesser volume of traffic. The life of adaptable asphalt is close around 15 years whose underlying expense is low needs an occasional support after a specific period and upkeep costs high. The life of inflexible asphalt is considerably more than the adaptable asphalt of around 40 years approx. 2.5 occasions life of adaptable asphalt whose underlying expense is considerably more than the adaptable asphalt, yet support cost is exceptionally less. (Saurabh Jain, Dr. Y. P. Joshi, S. S. Goliya (2013)

The Aim of this paper is thought about various kinds of adaptable asphalt structure to in different conditions. In this investigation an endeavor is made to look at the IRC strategy for adaptable asphalt configuration utilizing M-EPDG as far as its plan ideas and basic ampleness. It was seen that the IRC configuration overestimates the structure necessities for all the misery types with the exception of AC layer rutting. An update was done to amend this issue and the structure was advanced. From analysis and calculate design is prefer a AASHTO method for because it is provide $750 \mathrm{~mm}$ thickness as compare to IRC it is provide a $1000 \mathrm{mmthickness}$ for pavement so IRC is economical. $M r$ Sandeep $D$. Khorasiya (JUNE-2013)

\footnotetext{
* Corresponding author: author@e-mail.org
} 
The basic role of this paper has been to introduce ideas comparative with a technique for advancing certain choices the structure engineer must make while building up the plan of an asphalt. May be the most utility of the strategies can be acknowledged in creating territories where involvement in the current materials are small or totally inadequate. Recommended models are introduced for inspecting and determination of a plan esteem. It has been exhibited that the foreseen traffic and dampness condition at the site are significant components while choosing a structure an incentive from a progression of tests. Since the determination is constrained by the above elements combined with development and upkeep costs, solid evaluations of these amounts must be made for a given territory. E.J. Yoder (February-1969)

\section{Experimental Study of CBR Test}

It is the proportion of power per unit territory required to infiltrate a dirt mass with standard round cylinder at the pace of $1.25 \mathrm{~mm} / \mathrm{min}$ to that required for the relating entrance of a standard material.

$\mathrm{CBR}=($ Test load/Standard burden $) * 100$

The accompanying Table gives the standard burdens embraced for various entrances for the standard material with a CBR estimation of $100 \%$

Table.1 Values of penetration vs. Std. Load

\begin{tabular}{|c|c|}
\hline $\begin{array}{c}\text { Penetration of } \\
\text { plugger (mm) }\end{array}$ & Std. Load (kg) \\
\hline 2.50 & 1371 \\
\hline 5.00 & 2056 \\
\hline 7.50 & 2631 \\
\hline 10.00 & 3181 \\
\hline 12.50 & 3601 \\
\hline
\end{tabular}

The test may be performed on undisturbed specimens and on remolded specimen who may be compacted either statically or dynamically.

Table .2 CBR Values for Subgrade-1

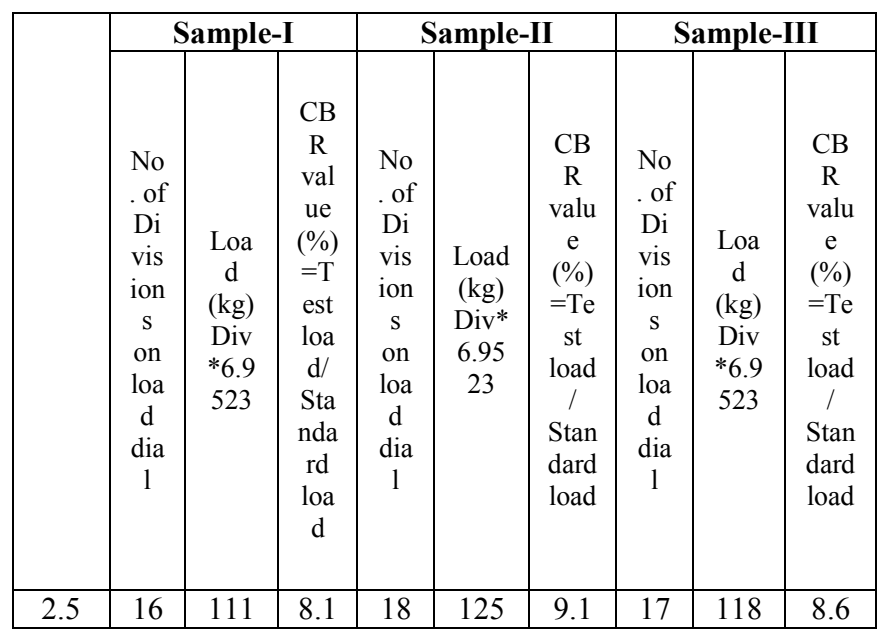

\begin{tabular}{|c|c|c|c|c|c|c|c|c|c|}
\hline 5.0 & 24 & 166 & 8.1 & 25 & 173 & 8.4 & 25 & 173 & 8.4 \\
\hline 7.5 & 30 & 208 & 7.9 & 29 & 201 & 7.6 & 31 & 215 & 8.1 \\
\hline 10.0 & 34 & 236 & 7.4 & 33 & 229 & 7.2 & 35 & 243 & 7.6 \\
\hline 12.5 & 37 & 257 & 7.1 & 37 & 257 & 7.1 & 37 & 257 & 7.1 \\
\hline
\end{tabular}

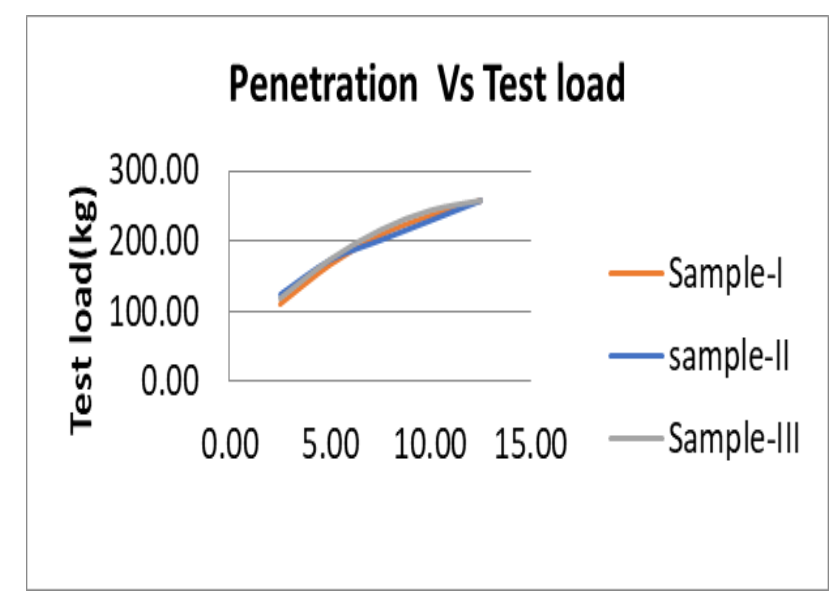

Fig.1 Penetration Vs Test Load

Table.3 CBR Values for Subgrade-2

\begin{tabular}{|c|c|c|c|c|c|c|c|c|c|}
\hline \multirow[b]{2}{*}{$\begin{array}{c}\text { Pen } \\
\text { etra } \\
\text { tion } \\
(\mathrm{m} \\
\mathrm{m})\end{array}$} & \multicolumn{3}{|c|}{ Sample-I } & \multicolumn{3}{|c|}{ Sample-II } & \multicolumn{3}{|c|}{ Sample-III } \\
\hline & $\begin{array}{c}\text { No. } \\
\text { of } \\
\text { Div } \\
\text { isio } \\
\text { ns } \\
\text { on } \\
\text { loa } \\
\text { d } \\
\text { dial }\end{array}$ & $\begin{array}{c}\text { Loa } \\
\mathrm{d} \\
(\mathrm{kg}) \\
\text { Div* } \\
6.95 \\
23\end{array}$ & $\begin{array}{c}\mathrm{CB} \\
\mathrm{R} \\
\mathrm{val} \\
\text { ue } \\
(\%) \\
=\mathrm{Te} \\
\mathrm{st} \\
\text { loa } \\
\mathrm{d} / \\
\mathrm{Sta} \\
\mathrm{nda} \\
\text { rd } \\
\text { loa } \\
\mathrm{d}\end{array}$ & $\begin{array}{c}\text { No. } \\
\text { of } \\
\text { Div } \\
\text { isio } \\
\text { ns } \\
\text { on } \\
\text { loa } \\
\text { d } \\
\text { dial }\end{array}$ & $\begin{array}{c}\text { Loa } \\
\mathrm{d} \\
(\mathrm{kg}) \\
\text { Div* } \\
6.95 \\
23\end{array}$ & $\begin{array}{c}\text { CB } \\
\text { R } \\
\text { val } \\
\text { ue } \\
(\%) \\
=T e \\
\text { st } \\
\text { loa } \\
\text { d/ } \\
\text { Sta } \\
\text { nda } \\
\text { rd } \\
\text { loa } \\
\text { d }\end{array}$ & $\begin{array}{c}\text { No } \\
\text {. } \\
\text { of } \\
D i \\
\text { vis } \\
\text { ion } \\
\text { s } \\
\text { on } \\
\text { loa } \\
\text { d } \\
\text { dia } \\
1\end{array}$ & $\begin{array}{l}\text { Lo } \\
\text { ad } \\
\text { (k } \\
\text { g) } \\
\text { Di } \\
v^{*} \\
6 . \\
95 \\
23\end{array}$ & $\begin{array}{c}\mathrm{CB} \\
\mathrm{R} \\
\text { valu } \\
\mathrm{e}(\% \\
) \\
=\mathrm{Te} \\
\mathrm{st} \\
\text { load } \\
/ \\
\text { Stan } \\
\text { dard } \\
\text { load }\end{array}$ \\
\hline 2.5 & 11 & 76.5 & 5.6 & 12 & 83.5 & 6.1 & 12 & 84 & 6.1 \\
\hline 5.0 & 16 & 112 & 5.4 & 16 & 112 & 5.5 & 16 & $\begin{array}{c}11 \\
2\end{array}$ & 5.4 \\
\hline 7.5 & 18 & 125 & 4.8 & 19 & 132 & 5.1 & 19 & $\begin{array}{c}13 \\
3\end{array}$ & 5.3 \\
\hline $\begin{array}{c}10 . \\
0\end{array}$ & 20 & 139 & 4.4 & 21 & 146 & 4.6 & 20 & $\begin{array}{c}13 \\
9 \\
\end{array}$ & 4.4 \\
\hline $\begin{array}{c}12 . \\
5\end{array}$ & 21 & 146 & 4.1 & 21 & 146 & 4.1 & 21 & $\begin{array}{c}14 \\
6\end{array}$ & 4.1 \\
\hline
\end{tabular}

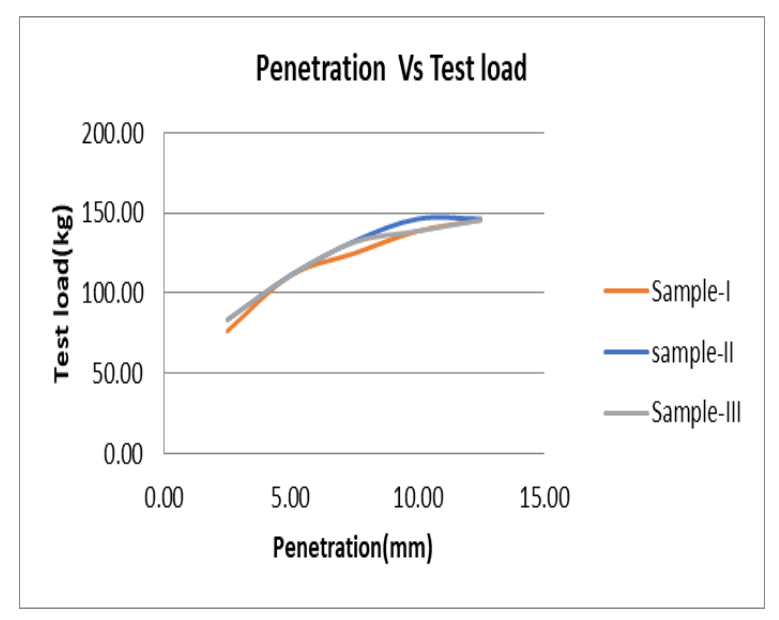

Fig.2 Penetration Vs Test Load 
CBR sub grade- $1=(8.10+9.10+8.6) / 3=8.65 \%$

CBR sub grade- $1=(5.60+6.10+6.1) / 3=6.00 \%$

Liquid Limit of subgrade-1 is $46 \%$

Liquid Limit of subgrade-1 is $46 \%$

Plastic Limit of sub grade- 1 is $15.5 \%$

Plastic Limit of sub grade-2 is $21.5 \%$

\section{Results and Disussions on Pavement Design}

Table.4 Experimental Result of Subgrades

\begin{tabular}{|l|c|c|}
\hline Description & Grade-1 & Grade-1 \\
\hline C BR & $9.0 \%$ & $6.0 \%$ \\
\hline LL & $46.0 \%$ & $47.0 \%$ \\
\hline PL & $15.5 \%$ & $21.5 \%$ \\
\hline
\end{tabular}

\section{CBR Method}

Cumulative traffic $150 \mathrm{msa}$

\section{Subgrade: 1}

CBR 9\% and for cumulative traffic $150 \mathrm{msa}$

The thickness of pavement is $655 \mathrm{~mm}$

The composition is maintained as per IRC $37-$

2001(shown below)

\section{Subgrade: 1}

CBR 6\% and for cumulative traffic $150 \mathrm{msa}$

The thickness of pavement is $720 \mathrm{~mm}$

The composition is maintained as per IRC 37-

2001(shown below)

Table.5 comparaisons of Pavement Thickness

\begin{tabular}{|c|c|c|c|}
\hline $\begin{array}{c}\text { Diffèrent } \\
\text { Test }\end{array}$ & $\begin{array}{c}\text { Thickness of } \\
\text { bitumen for } \\
\text { sub grade } \\
\mathbf{1 ( m m )}\end{array}$ & $\begin{array}{c}\text { Thickness of } \\
\text { bitumen for } \\
\text { sub grade } \\
\mathbf{1 ( m m )}\end{array}$ & $\begin{array}{c}\text { Difference } \\
\text { (mm) }\end{array}$ \\
\hline $\begin{array}{c}\text { CBR } \\
\text { Method of } \\
\text { design }\end{array}$ & 655 & 720 & 65 \\
\hline
\end{tabular}

From the above values we can observe that sub grade-1 is stronger than sub grade- 2 .

\section{Conclusions}

The flexible pavement thickness is designed for sub grade soils as per IRC:37-2001 code and the results are compared. The pavement thickness is calculated by two methods California Bearing Ratio (CBR) method the following conclusions are made:

1. Standard compaction test we found the Dry density and OMC values for both the sub grades, the dry density value of sub grade-1 is more than dry density value of sub grade- 2 .

2. CBR test found that CBR value of two sub grades which is more for subgrade-2 compared to sub grade-1.

3. Grain size distribution we have concluded that sub grade-1 is well graded and sub grade-2 is poorly graded.

4. The design pavement thickness for sub grade-2 increases by $9.92 \%$ (difference is $65 \mathrm{~mm}$ ) compared to design pavement thickness of sub grade-1 in CBR method.

5. Sub grade- 1 is stronger than sub grade- 2 .

\section{References}

1. Saurabh Jain et al. Int. Journal of Engineering Research and Applications Vol. 3, Issue 5.

2. IRC: 37-2001 "Guidelines for the Design of Flexible Pavements", Second Revision, Indian Roads Congress.

3. IRC: 58-2002 "Rules for the Design of Plain Jointed Rigid Pavements for Highways", Second Revision, Indian Roads Congress

4. Anchula Nagarjuna, T. Suresh Kumar, B.Yogeswara Reddy, M.Udaykiran, International Journal of Innovative Technology and Exploring Engineering, Vol. 8 no. 11, pp: 640-645, (2019)

5. H Huang (2004) "Pavement Analysis and Design", 2nd edition, Prentice Hall Yoder and Witzack (1975) "Principles of Pavement Design", 2nd edition, John Wileys and Sons.

6. Mohammed Hussain, Y. Kamala Raju "Fitting Infiltration Equations using Double Ring Infiltrometer to Design and Evaluate Irrigation Methods" IJRTE, Volume-8 Issue-4, Nov 2019.

7. Text book of "Highway Engineering "by S.kanna and Justeo.

8. Y. Kamala Raju, N. Tejaswi, S. Anjali Reddy "Reinforced Cement Concrete Cylindrical Shell for Parking Sheds" TEST Engineering \& Management magazine, May -June 2020, Volume 83, Vol. 83: May/June 2020,

9. M. S. Britto Jeyakumar, Y. Kamala Raju "Characteristics of Paper brick with Inequitable Substitution of Cement" IJITEE, Volume-8 Issue12S, October 2019, PP 85-88

10. Y. Kamala Raju, M.S. Britto Jeyakumar "Modulus Of Elasticity On High Performance Glass Fibre RCC Beams With Partial Replacement Of Cement By Silica Fume" IJITEE Volume-8 Issue-10, August 2019,

11. Y. Kamala Raju and Rathod Ravinder "Reverse Osmosis Plant Design and Evaluation - A Case Study" International Journal of Latest Trends in Engineering and Technology IJLTET, Vol.(10) Issue(3), May 2018.

12. Y. Kamala Raju, R. Meher Babu and Mohd. Husssain "Reinforced Cement Concrete Bridge Deck Design of a Flyover with Analysis for Dynamic Response Due to Moving Loads for Urban Development in Transportation Systems - A Case Study" IJERMCE, Vol 3, Issue 2, Feb 2018. PP 121-128.

13. Y. Kamala Raju, N. Harish Kumar (2019)"Strength Performance of Crumb Rubber Concrete ", Volume 7, Issue V, IJRASET Page No 2007-2010. 